\title{
Leptin receptor signaling inhibits ovarian follicle development and egg laying in chicken hens
}

\author{
Ming M Lei ${ }^{1}$, Si Q Wu' ${ }^{2}$, Xiao W Li ${ }^{2}$, Cong L Wang ${ }^{2}$, Zhe Chen ${ }^{1}$ and Zhen D Shi ${ }^{1 *}$
}

\begin{abstract}
Background: Nutrition intake during growth strongly influences ovarian follicle development and egg laying in chicken hens, yet the underlying endocrine regulatory mechanism is still poorly understood. The relevant research progress is hindered by difficulties in detection of leptin gene and its expression in the chicken. However, a functional leptin receptor (LEPR) is present in the chicken which has been implicated to play a regulatory role in ovarian follicle development and egg laying. The present study targeted LEPR by immunizing against its extracellular domain (ECD), and examined the resultant ovarian follicle development and egg-laying rate in chicken hens.

Methods: Hens that have been immunized four times with chicken LEPR ECD were assessed for their egg laying rate and feed intake, numbers of ovarian follicles, gene expression profiles, serum lipid parameters, as well as STAT3 signaling pathway.

Results: Administrations of CLEPR ECD antigen resulted in marked reductions in laying rate that over time eventually recovered to the levels exhibited by the Control hens. Together with the decrease in egg laying rate, cLEPR-immunized hens also exhibited significant reductions in feed intake, plasma concentrations of glucose, triglyceride, high-density lipoprotein, and low-density lipoprotein. Parallelled by reductions in feed intake, mRNA gene expression levels of AgRP, orexin, and NPY were down regulated, but of POMC, MC4R and lepR up-regulated in Immunized hen hypothalamus. CLEPR-immunization also promoted expressions of apoptotic genes such as caspase3 in theca and fas in granulosa layer, but severely depressed IGF-I expression in both theca and granulosa layers.

Conclusions: Immunization against CLEPR ECD in egg-laying hens generated antibodies that mimic leptin bioactivity by enhancing leptin receptor transduction. This up-regulated apoptotic gene expression in ovarian follicles, negatively regulated the expression of genes that promote follicular development and hormone secretion, leading to follicle atresia and interruption of egg laying. The inhibition of progesterone secretion due to failure of follicle development also lowered feed intake. These results also demonstrate that immunization against CLEPR ECD may be utilized as a tool for studying bio-functions of CLEPR.
\end{abstract}

Keywords: Chicken leptin receptor, Extra-cellular domain, Antibody, Ovarian follicule development, Gene expression, Hens

\section{Background}

Leptin, secreted by the white adipocytes, plays important roles in regulating appetite, metabolism and energy homeostasis [1-3]. Leptin serves as a signal of the body fat content or energy reserve $[4,5]$ for the brain to reduce food intake [6,7], and for the peripheral tissues to increase energy expenditure $[1,8,9]$, and utilize the energy reserve and fat storage [10]. In addition, leptin is

\footnotetext{
*Correspondence: zdshi@jaas.ac.cn

'Laboratory of Animal Breeding and Reproduction, Institute of Animal Science, Jiangsu Academy of Agricultural Sciences, Nanjing 210014, China Full list of author information is available at the end of the article
}

also instrumental to the initiation and the maintenance of the reproductive activities through its action in the hypothalamus to facilitate gonadotropin secretions [4,11-14]. Leptin has also been reported to directly antagonize ovarian estradiol and progesterone secretions stimulated by gonadotrophin follicle stimulating hormone (FSH) [15] or insulin-like growth factor I (IGF-I) $[16,17]$, thereby inhibiting ovarian follicle development. Leptin has been reported to reduce cultured rat follicle growth speed and granulosa cell numbers [18], and decreased luteinizing hormone $(\mathrm{LH})$ induced ovulations 
[19]. These inhibitory regulatory roles of leptin are conserved in chickens, as the ovarian follicle development is often perturbed in overweight hens [20,21], and that leptin has been observed to induce apoptosis of cultured chicken granulosa cells [22]. Nevertheless, much controversy exists over the presence of the chicken leptin gene or its protein product [3,23-26]. Difficulties in detecting leptin gene and products, together with the requirement for large quantities of leptin hormone in the case of administration studies, have hindered research into regulation of reproductive activities by leptin in chicken hens.

Fortunately, the leptin receptor (lepR) gene is present in the chicken genome $[27,28]$ and its protein product, the leptin receptor protein (LEPR), functions to mediate hormone bioactivities [29]. For example, in vivo administrations of leptin from chicken and other species depressed chick feed intake [7], blood triglyceride concentrations [30], and accelerated reproductive development [31]. Furthermore, immunization against leptin stimulated abdominal fat deposition and feed intake [32]. These results of leptin administration and immunoneutralization should be mediated via LEPR signaling channels.

Since hormones fulfill their regulatory roles through the receptors, one could probe the signal transduction mechanism of the hormone by employing specific binding molecules that mimic hormonal actions [33-36]. Therefore, leptin-mediated regulation of the chicken ovarian follicular development could be studied by manipulating LEPR instead of using leptin directly. Previous studies have demonstrated that immunization against receptor extracellular domains (ECDs) could produce both anta- and agonistic effects [37], and that such a method could be adopted to study endocrine regulation of chicken ovarian follicular development [38]. The cLEPR possesses a long ECD, extending up to 810 amino acid residues [27]. Immunization against the domain proximal to the cell membrane has showed to mimic leptin signaling and reduced fat deposition in rats [unpublished data], and weight loss in chickens [unpublished data]. In the present study, we immunized the domain distal to the membrane, or the $\mathrm{N}$-terminal domain of LEPR, to study its effects on ovarian follicle development in the laying hens, in terms of egg-laying performance, follicular atresia, gene expression and feed intake.

\section{Methods}

\section{Obligatory ethical approval}

The experiment was approved by the Research Committee of Jiangsu Academy of Agricultural Sciences and conducted with adherence to the Regulations for the Administration of Affairs Concerning Experimental Animals (Decree No.2 of the State Science and Technology Commission on November 14, 1988).

\section{Preparation of immunogens}

A chicken LEPR ECD fusion protein, including a 36residue leading sequence derived from the expression plasmid pRSETA (Invitrogen, Carlsbad, CA, USA), and the 200-residue sequence spanning from the $\mathrm{N}$-terminal $101^{\text {st }}$ to $300^{\text {th }}$ amino acid residue of cLEPR, was expressed in E. coli strain BL21 (DE3). This cLEPR recombinant protein which was 236 amino acid residues long was purified to homogeneity by chromatography with Ni-NTA resin (Qiagen). The pure protein was then dissolved in a water/Grade 10 Injection white oil (Hangzhou Refinery, Hangzhou, China) mixture (in volume, $40 \%$ water and $60 \%$ oil) to reach a final concentrations of 1 and $2 \mathrm{mg} / \mathrm{mL}$. The resulted emulsion was used as the immunogen in the experiment. A bovine serum albumin (BSA) immunogen was also prepared with the same method, with a final concentration of $1 \mathrm{mg} / \mathrm{mL}$ and $2 \mathrm{mg} / \mathrm{mL}$.

\section{Animals and treatments}

Sixty Yuehuang hens, 152-day old, were equally allocated into Control and cLEPR Immunized groups (each group $\mathrm{n}=30$ ). The hens were kept individually in battery cages, exposed to a $16 \mathrm{~h}$ light regime daily, and fed ad libitum a laying diet of $18 \%$ crude protein and $11.33 \mathrm{MJ} / \mathrm{kg}$ metabolizable energy. Egg laying was recorded daily at 17:00 and mean egg laying rate was calculated on a weekly basis. On day 1 of the experiment, the Immunized group was administered intramuscularly $1 \mathrm{ml}$ CLEPR immunogen containing $1 \mathrm{mg}$ of the recombinant CLEPR protein. Booster immunizations were performed on day 21, 63 and 91 with $1 \mathrm{ml}$ cLEPR immunogen containing $2 \mathrm{mg}$ of the recombinant CLEPR protein. Similarly, Control hens were treated with $1 \mathrm{ml}$ BSA immunogen on day 1 of the experiment and booster immunizations were performed on day 21, 63 and 91 with $1 \mathrm{ml}$ control immunogen containing $2 \mathrm{mg}$ of the BSA. During the experiment, blood samples were collected, at 2 week intervals, by venipuncture of wing veins from 12 birds in each group, into a syringe containing $100 \mathrm{IU}$ of heparin. The plasma was isolated by centrifugation at $1,000 \mathrm{~g}$ and stored at $-20^{\circ} \mathrm{C}$ until analyzes until measurements of antibody titer. Blood serums collected on d 35 of the experiment were used for concentration measurements of glucose, triglycerides, cholesterol, high-density lipoprotein (HDL), low-density lipoprotein (LDL), and very low-density lipoprotein (VLDL).

On day 95, when egg laying started to decrease again in the Immunized cLEPR hens, all hens in each group were slaughtered. Ovarian follicles were collected and the numbers of large yellow follicles (LYF) and atretic follicles were recorded. From the largest five LYFs (F1 to F5) were granulosa and theca layers separated or isolated. The isolates were frozen in liquid nitrogen and subsequently stored under $-70^{\circ} \mathrm{C}$ for gene expression 
analyses. Liver and adipose tissue samples also were collected, and snap frozen in liquid nitrogen.

\section{Measurement of blood anti-cLEPR antibody titer}

A standard enzyme linked immunosorbent assay (ELISA) method was utilized to measure anti-cLEPR antibody titers in plasma. The recombinant cLEPR protein was used to coat the 96-well microtiter plates (5 g /well in $250 \mathrm{~L}$ ). After blocking the plate with $1 \%$ skim milk and washing, $100 \mathrm{~L}$ of plasma sample, diluted 1:800 with $1 \%$ skimmed milk, was added to each well and incubated with anticLEPR antibody. The bound antibody was further labeled by addition of horse radish peroxydase (HRP)-conjugated sheep-anti-chicken antibody (Santa Cruz Biotechnology, CA, USA). Detection of the bound antibody was initiated by addition of chromogen tetraethyl benzidine (Sigma Chemical Co, St Louis, USA) solution containing 0.03\% $\mathrm{H}_{2} \mathrm{O}_{2}$, and terminated with the addition of $2 \% \mathrm{H}_{2} \mathrm{SO}_{4}$. Optical absorbance at $450 \mathrm{~nm}$, representing anti-cLEPR antibody titer, was measured. To overcome assay bias between treatment groups, samples from each collection occasions were measured on the same plate.

\section{Western blotting}

Liver tissue was homogenized and centrifuged. Approximately $30 \mu \mathrm{g}$ of the supernatant was mixed with $2 \times$ Laemmli buffer (Sigma-Aldrich Corp., Saint Louis, MO), denatured, resolved on a denaturing PAGE, and transferred to a nitrocellulose membrane. The anti-stat3 and anti-beta-actin primary antibodies (1:200, Cell Signaling Technology, Inc., Boston, MA); and the anti-rabbit secondary antibody (1:50,000 Cell Signaling Technology, Inc., Boston, MA) were used for detection. The signal was developed using SuperSignal West-Pico kit (Thermo Fisher Scientific, Waltham, MA).

\section{Assays of serum glucose, triglycerides, cholesterol, HDL, LDL and VLDL}

Concentrations of glucose, triglycerides, cholesterol, HDL, LDL, and VLDL were measured by using a ROCHE Modular P800 Automatic Biochemical Analyzer (Roche Diagnostics).

\section{Measurements of gene expressions}

Real-time quantitative PCR was performed for quantification of $\beta$-actin, agouti-related peptide gene (AgRP), neuropeptide $Y$ (NPY), Proopiomelanocortin (POMC), Melanocortin 4 receptor $(M C 4 R)$, orexin, lepR, and gonadotrophin- releasing hormone I (GnRH-I) mRNA expression levels in the hypothalamus, $L H \beta$ and $F S H \beta$ in pituitary gland, $P P A R \gamma$ in the abdominal fat tissue and liver, FSHR, LHR, IGF-I, fas, caspase3, bcl2, steroidogenic acute reguated protein (StAR), cytochrome P450, family
19, subfamily $A$, polypeptide 1(CYP19A1), and cytochrome P450, family 17, subfamily $A$, polypeptide 1 (CYP17A1) in ovarian granulosa and theca layers (Table 1). Total RNA was extracted from each tissue using Trizol (Invitrogen), and reverse transcribed to cDNA using ReverTra Ace qPCR RT Kit (Toyobo, Osaka, Japan). PCR reactions were carried out in a $50 \mu \mathrm{l}$ reaction volume with SYBR Green I Master Mix reagent (Toyobo, Osaka, Japan) and 2.5 pmol specific primer pairs shown in Table 1. An ABI PRISM_7500 sequence detection system (Applied Biosystems, Foster City, CA, USA) was used to detect the amplification products. Upon completion of the real-time Q-PCR, threshold cycle $(\mathrm{Ct}$, defined as the cycle at which a statistically significant increase in the magnitude of the signal generated by the PCR reaction was first detected) values were calculated by sequence detection software SDS Version 1.2.2 (Applied Biosystems). The levels of gene expression were expressed in the form of $2^{-\Delta \Delta C t}$.

\section{Statistical analysis}

Differences between the Immunized and Control groups, in terms of anti-cLEPR ECD antibody titer, feed intake, the numbers of follicles, were analyzed by one-way analysis of variance. Differences of gene expression in hypothalamus, pituitary gland, the abdominal fat tissue, liver, and plasma concentrations of glucose, triglycerides, cholesterol, HDL, LDL, and VLDL were also analyzed by oneway analysis of variance. The means were compared by the LSD method. The data of gene expression in ovarian granulosa and theca layers were analyzed using the mixed model by SAS statistics software. The treatment group and various sizes of ovarian follicles were designated as fixed factors, while the hen identity was designated as the random factor. The means were compared with least squares means. All values are expressed as mean \pm SEM. All statistical analyses were performed with SAS software Version 8.01 (SAS Institute Inc. Cary, NC. USA).

\section{Results}

\section{Anti-cLEPR antibody titre}

Antibody titers were measured by ELISA as optical density (OD) value at $450 \mathrm{~nm}$. Throughout the experiment, the OD values were barely detectable in plasma samples of the Control hens, which were considered to be the non-specific binding of the assay. Fourteen days after the primary immunization, the anti-cLEPR antibody titer had already increased $(P<0.05)$ above the pre-immunized non-specific binding levels, and was further increased following the second or $1^{\text {st }}$ booster immunization $(P<0.01)$. The titers in the Immunized hens were maintained at high levels following the $2^{\text {nd }}$ and $3^{\text {rd }}$ booster immunizations on day 63 and 91, respectively (Figure 1A). 
Table 1 Primers used in the real-time quantitative PCR of genes in chicken samples

\begin{tabular}{|c|c|c|c|}
\hline Gene & Accession number & Primer sequences $\left(5^{\prime}-3^{\prime}\right)$ & Length(bp) \\
\hline \multirow{2}{*}{$\beta$-actin } & \multirow{2}{*}{ L08165 } & upstream: CCGAGAGAGAAATTGTGCGTGAC & \multirow{2}{*}{166} \\
\hline & & downstream: TCGGGGCACCTGAACCTCTC & \\
\hline \multirow{2}{*}{$F S H \beta$} & \multirow{2}{*}{ AY029204 } & upstream: GGCTGCGGTGACCATCCTGAATC & \multirow{2}{*}{101} \\
\hline & & downstream: GGCCCCAGTCCTCTCACAGTGCA & \\
\hline \multirow{2}{*}{ GnRH-I } & \multirow{2}{*}{ JN609557 } & upstream:TGTCCTCCTGTTCACCGCATCTG, & \multirow{2}{*}{222} \\
\hline & & downstream: TCGATCAGGCTTGCCATGGTITC & \\
\hline \multirow{2}{*}{$L H \beta$} & \multirow{2}{*}{ HQ872606 } & upstream:GGGGGGAGCGCAGGTGTTG & \multirow{2}{*}{220} \\
\hline & & downstream: CCCGCAGGCCGTGGTGGT & \\
\hline \multirow{2}{*}{$A g R P$} & \multirow{2}{*}{ AB029443 } & upstream: TCCCCTCGCCGCTGTGTC & \multirow{2}{*}{137} \\
\hline & & downstream: CATGGGAAGGTGGTGCTGATC & \\
\hline \multirow{2}{*}{ NPY } & \multirow{2}{*}{ NM_205473 } & upstream: GGAAAGAGATCAAGCCCAGAGAC & \multirow{2}{*}{193} \\
\hline & & downstream: ATGCACTGGGAATGACGCTATG & \\
\hline \multirow{2}{*}{ orexin } & \multirow{2}{*}{ AB056748 } & upstream: CGCTGGGCAAGAGGAAGAG & \multirow{2}{*}{117} \\
\hline & & downstream: GGCGCTCCTCACGTITGC & \\
\hline \multirow{2}{*}{ MC4R } & \multirow{2}{*}{ AY545056 } & upstream: GCCAAGAACAAGAACCTCCATT & \multirow{2}{*}{150} \\
\hline & & downstream: TATGGTAAAGCTCTGTGCGTCTG & \\
\hline \multirow{2}{*}{ POMC } & \multirow{2}{*}{ NM_001031098 } & upstream: GGCCGAGGCACCCGTGTAC & \multirow{2}{*}{141} \\
\hline & & downstream: GCGGGGTGGTGGGGTGAC & \\
\hline$I E P R$ & N114 201323 & upstream: TTTCTGTTGGGCTTTCTTCAC & 148 \\
\hline LLT & 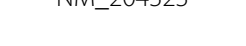 & downstream: AACCAGACCGGCTCCGTACA & 140 \\
\hline ECHP & (1) 205070 & upstream: TCCCACCAATGCCACAGAAC & 155 \\
\hline 位 & TNIVI_COSO/9 & downstream: TGGGAAGGCTGGAAAACACA & 153 \\
\hline 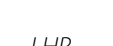 & 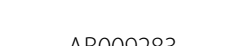 & upstream: GGGCATGAGCAACGAATCG & 121 \\
\hline$L \Pi K$ & $A D 009 \angle 03$ & downstream: CCGCCTGAGGTITTGTTGTC & 124 \\
\hline $1 C 51$ & ALA 001001304 & upstream: TGCTGCTTTTGTGATTTCTTGAA & 120 \\
\hline $\mid N T-1$ & TVIVI_OU I00 4504 & downstream: AACCAGCTCAGCACCACACAGT & 130 \\
\hline 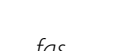 & NMM 001199487 & upstream: TTCCCACACACACTGCACATAA & 153 \\
\hline Mas & TIVI_OU I 19940\% & downstream: CACACCGAGAAGAATTGCAGTAA & \\
\hline casnasez & NM 204725 & upstream: CCACGCTCAGGGGAAGATGTAT & 173 \\
\hline caspuses & TIVI_CO4/ZS & downstream: CGGTATCTCGGTGGAAGTTCTTA & \\
\hline$h c / 2$ & 개 205330 & upstream: CGCCGCTACCAGAGGGACTTC & 107 \\
\hline $0 \mathrm{Clz}$ & ה9 & downstream: CGCCGCCGAACTCGAAGAAG & 192 \\
\hline$c \in 0$ & 194 204686 & upstream: GCCGGACGTGGGTAAGGTGT & $10 \mathrm{P}$ \\
\hline SIAK & TIIVI_2U4080 & downstream: CGCCGTCTCGTGGGTGATC & 184 \\
\hline CYO101 1 & D) 00100176 & upstream: TGCCAGTTGCCACAGTGCCTATC & 117 \\
\hline CYPISAI & NIM__001001/61 & downstream: GGCCCAATTCCCATGCAGTATC & 112 \\
\hline CYP17A1 & N10 001001756 & upstream: CGGGCAGCTTTCAGGCATG & 180 \\
\hline CPFIIAI & TIVI_UOIOUT/50 & downstream: TGGCCATGATGTTGTGCACGTT & 109 \\
\hline DOPD & 18045507 & upstream: GCTCCAGGATTGCCAAAGTG & 127 \\
\hline$P T A R$ & $A D U 45391$ & downstream: TCCCCACACACACGACATTCA & 13/ \\
\hline
\end{tabular}

\section{Egg laying rate}

Throughout the entire experimental period, the daily egglaying rate in the Control hens remained relative stable, between $60 \%$ and $75 \%$. However, in the Immunized hens, the rate started to decrease from $68 \%$ at the beginning of the experiment to approximately $55 \%$ around day 10 


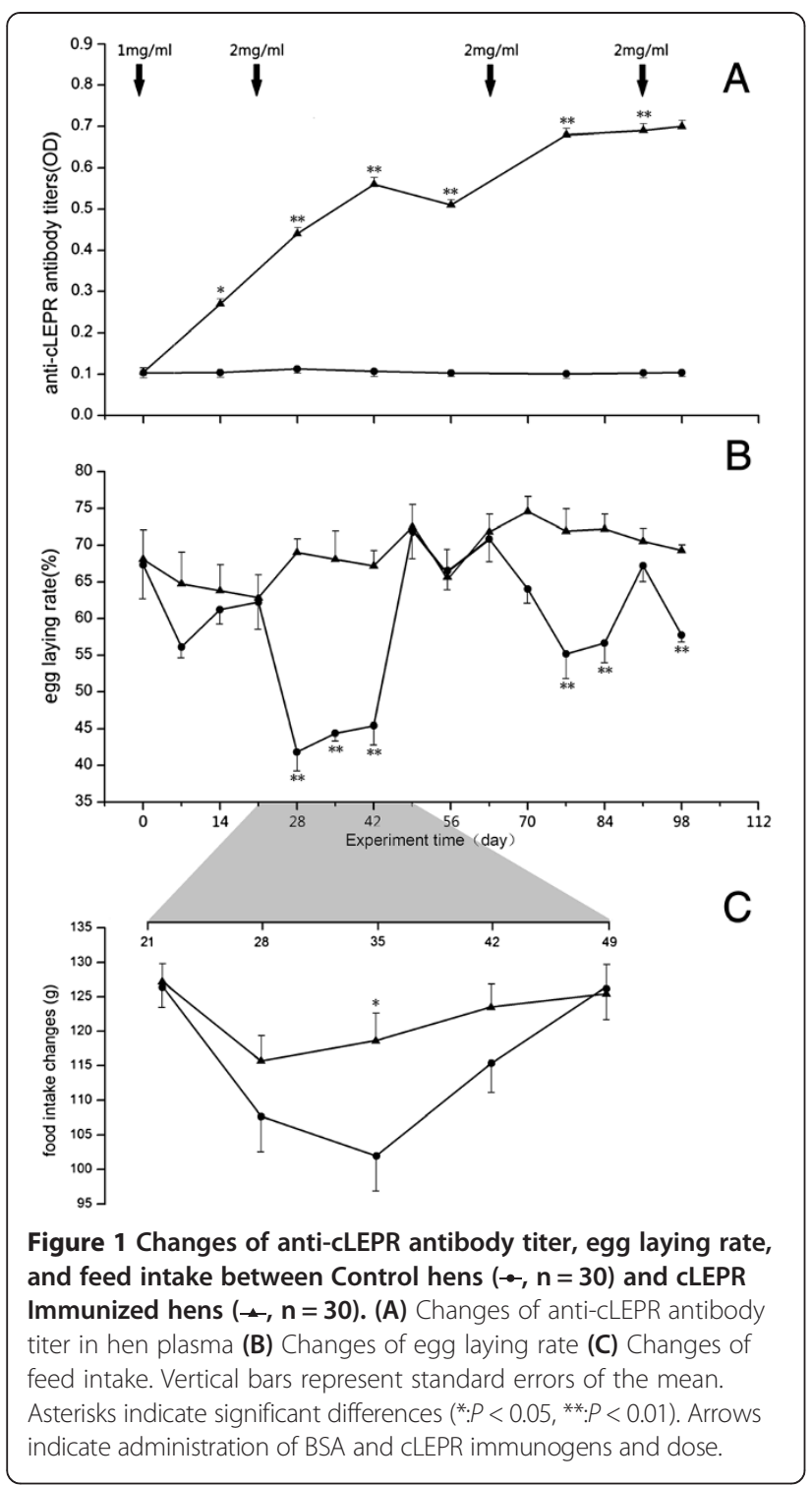

after the primary immunization (cLEPR dose $1 \mathrm{mg} / \mathrm{ml}$ ) (Figure 1B). The rate subsequently increase to the level comparable to that in the Control group during the third week of the experiment $(P>0.05)$. However, the rate dropped sharply from the 4th week. After the first booster immunization (cLEPR dose $2 \mathrm{mg} / \mathrm{ml}$ ), the egg laying rate went to a level below $45 \%$ and significantly lower $(P<0.01)$ than the rate in the Control hens. The laying rate remained depressed for further two weeks during the 5th and 6th week of the experiment, before rising back to control levels again at the 7th week of the experiment. The drops and rebounds of egg laying rate reappeared following the second booster cLEPR immunization, albeit with smaller magnitude and shorter duration (Figure 1B). Finally, the $4^{\text {th }}$ cLEPR immunization brought about a small drop of egg laying within five days before the hens were slaughtered (Figure 1B).

\section{Feed intake during egg laying drop}

Measured during the expected egg laying decrease, following the first booster immunization, the feed intake of the Control group slightly decreased to $115 \mathrm{~g}$ in the first week, but thereafter gradually recovered to normal levels of $125 \mathrm{~g}$ in the following three weeks. The post-immunization drop of feed intake, however, was more marked in the Immunized hens, which, by day 35 of the experiment, was below $105 \mathrm{~g}$. As the laying rate started to rebound after day 35 , so did the feed intake, which recovered to the normal levels exhibited by the Control hens (Figure 1C). The difference in feed intake on day 35 was statistically significant between the Control group (118.66 $\pm 3.99 \mathrm{~g})$ and Immunized group of chickens $(101.97 \pm 5.14 \mathrm{~g},(\mathrm{P}<0.05))$.

\section{Plasma metabolite concentrations}

On day 35 of the experiment, i.e. when the egg laying rate and feed intake were minimal in the Immunized hens, after the first booster immunization, the plasma concentrations of triglycerides and HDL in Immunized CLEPR chickens were significantly lower than those in the Control chickens $(P<0.01)$ (Table 2$)$, as were the concentrations of serum glucose and VLDL $(p<0.05)$. On the other hand, the concentrations of LDL in Immunized cLEPR chickens were significantly higher than in the Control chickens $(P<0.05)$.

\section{Ovarian follicle numbers}

On day 5 after the $3^{\text {rd }}$ booster immunization with $2 \mathrm{mg}$ of cLEPR immunogen, the Immunized hens had lower number of small yellow follicles (SYF) $(P<0.05)$, but greater number of atretic follicles $(P<0.05)$, compared to the Control hens (Table 3). Although the Immunized hens also had fewer numbers of LYF and large white follicle (LWF), compared to those of the Control hens, the differences were not statistically significant $(P>0.05)$.

Table 2 Concentrations of total glucose, triglycerides, cholesterol, HDL, LDL, and VLDL in hens (sera collected on d 14 after the first booster immunization, mean $\pm S E M, m m o l / L, ~ n=24)$

\begin{tabular}{lcccccc}
\hline & Blood glucose & triglyceride & cholesterol & HDL & LDL & VLDL \\
\hline Controls & $14.088 \pm 0.28^{\mathrm{a}}$ & $17.1 \pm 1.44^{\mathrm{a}}$ & $4.91 \pm 0.43^{\mathrm{a}}$ & $2.1 \pm 0.40^{\mathrm{a}}$ & $0.83 \pm 0.08^{\mathrm{a}}$ & $1.99 \pm 0.26^{\mathrm{a}}$ \\
CLEPR-immunized & $12.97 \pm 0.28^{\mathrm{b}}$ & $12.07 \pm 1.50^{\mathrm{c}}$ & $4.02 \pm 0.34^{\mathrm{a}}$ & $1.19 \pm 0.08^{\mathrm{c}}$ & $1.43 \pm 0.16^{\mathrm{b}}$ & $1.39 \pm 0.25^{\mathrm{b}}$ \\
\hline
\end{tabular}

Note: Means in the same column marked with different superscript letters differ significantly $\left({ }^{\mathrm{a}-\mathrm{b}:} P<0.05 ;{ }^{\mathrm{a}-\mathrm{c}:} P<0.01\right)$. 
Table 3 Number of ovarian follicles counted on day 5 after the $4^{\text {st }}$ administration (mean $\pm S E M, n=8$ )

\begin{tabular}{lcc}
\hline Types of follicles & Controls & Immunized \\
\hline Large yellow follicles & $4.2 \pm 2.0^{\mathrm{a}}$ & $2.4 \pm 2.5^{\mathrm{a}}$ \\
Small yellow follicles & $8.4 \pm 2.6^{\mathrm{a}}$ & $4.8 \pm 1.8^{\mathrm{b}}$ \\
Large white follicles & $19.2 \pm 9.3^{\mathrm{a}}$ & $14.8 \pm 8.0^{\mathrm{a}}$ \\
Atretic follicle & $0 \pm 0^{\mathrm{a}}$ & $4.0 \pm 0.9^{\mathrm{b}}$ \\
\hline
\end{tabular}

Note: Values in the same row with different superscript letters differ significantly $\left({ }^{\mathrm{a}-\mathrm{b}}, P<0.05\right)$. Data are mean $\pm \operatorname{SEM}(n=8)$.

\section{Phosphorylated STAT3 of JAK2/STAT pathway}

On day 5 after the $3^{\text {rd }}$ booster immunization, with $2 \mathrm{mg}$ of cLEPR immunogen, the cLEPR Immunized groups had 2fold increase of phosphorylated STAT3 proteins as quantified by the Western blot analysis in the liver tissue homogenate than in the Control group (Figure $2 \mathrm{~A}$ and $\mathrm{B})(P<0.01)$.

\section{Gene expression}

Follicle development regulating genes

Following cLEPR immunization, the expressions of lepR and caspase 3 mRNA were strongly up- regulated in the granulosa layer in the F1 to F5 follicles $(P<0.01)$, while the expression level of fas was marginally but not statistically $(P>0.05)$ significantly up-regulated. However, fas expression was strongly up-regulated $(P<0.01)$ in the theca layer in F1 to F3 follicles. On the contrary, the expression of $b c l 2$ was slightly down-regulated in theca and granulosa layers, with more significant decrease in F5 and F2 follicles respectively (Figure 3).

The expressions of LHR, StAR, FSHR and IGF-I were down-regulated $(P<0.05)$ following CLEPR immunization in the granulosa layer in all class of follicles, and also in theca layer for the latter two genes. In the theca layer, $L H R$ expression was significantly lower $(P<0.05)$ in $\mathrm{F} 5$ follicle, but its expression only dropped slightly in other larger follicles, in CLEPR immunized hens. In the cases of CYP17A1 and CYP19A1, expression in granulosa layer was downregulated in F1 follicles $(P<0.01$ and $P<0.05$ respectively).

\section{Gonadotrophic hormone genes}

The expressions of the GnRH-I gene in the hypothalamus and the $L H \beta$ gene (especially FSH $\beta(P<0.05)$ gene) in pituitary gland were up-regulated following cLEPR immunization (Figure 4).

\section{PPARY MRNA expression}

The expression level of PPAR $\gamma$ mRNA were up-regulated $(P<0.05)$ in the liver, down-regulated $(P<0.01)$ in the abdominal fat tissues, following cLEPR immunization (Figure 2C and D).

\section{Appetite regulating genes}

The expressions of the appetite-stimulating gene in the hypothalamus, AgRP, orexin were all down-regulated
A

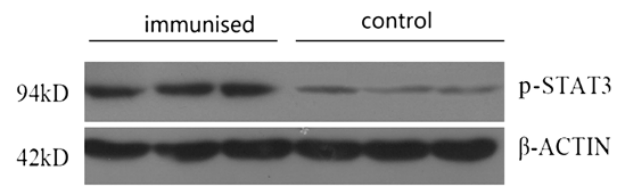

B

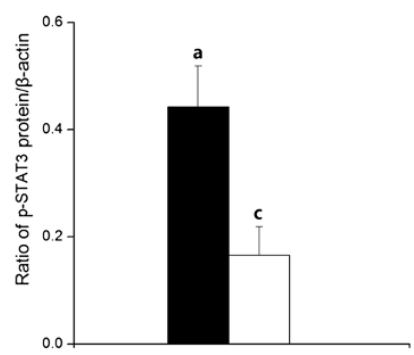

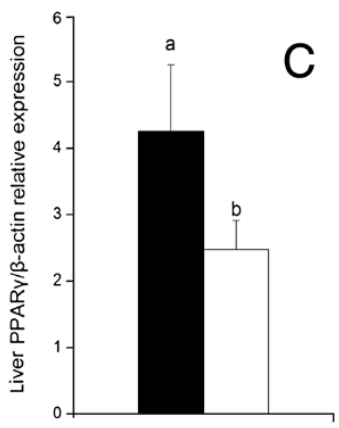

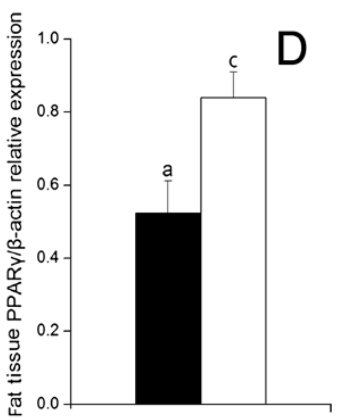

Figure 2 Ratio of p-STAT3 protein/ $\beta$-actin and levels of PPAR $\gamma$ mRNA expression between Control hens $(\square, \mathrm{n}=8$ ) and $c L E P R$ Immunized hens $(\mathbf{\square}, \mathbf{n}=\mathbf{8})$. (A) Western blot of p-STAT3 (the band intensity was normalized to $\beta$-actin) (B) Ratio of p-STAT3 protein/ $\beta$-actin (the ratios were used to analyze significant difference) (C) PPARY mRNA expression in liver (D) PPARY mRNA expression in abdominal fat tissues. Vertical bars represent the standard errors of the mean. Means not marked by a common letter are significantly different $(a-b$ : $P<0.05 ; a-c: P<0.01)$. 


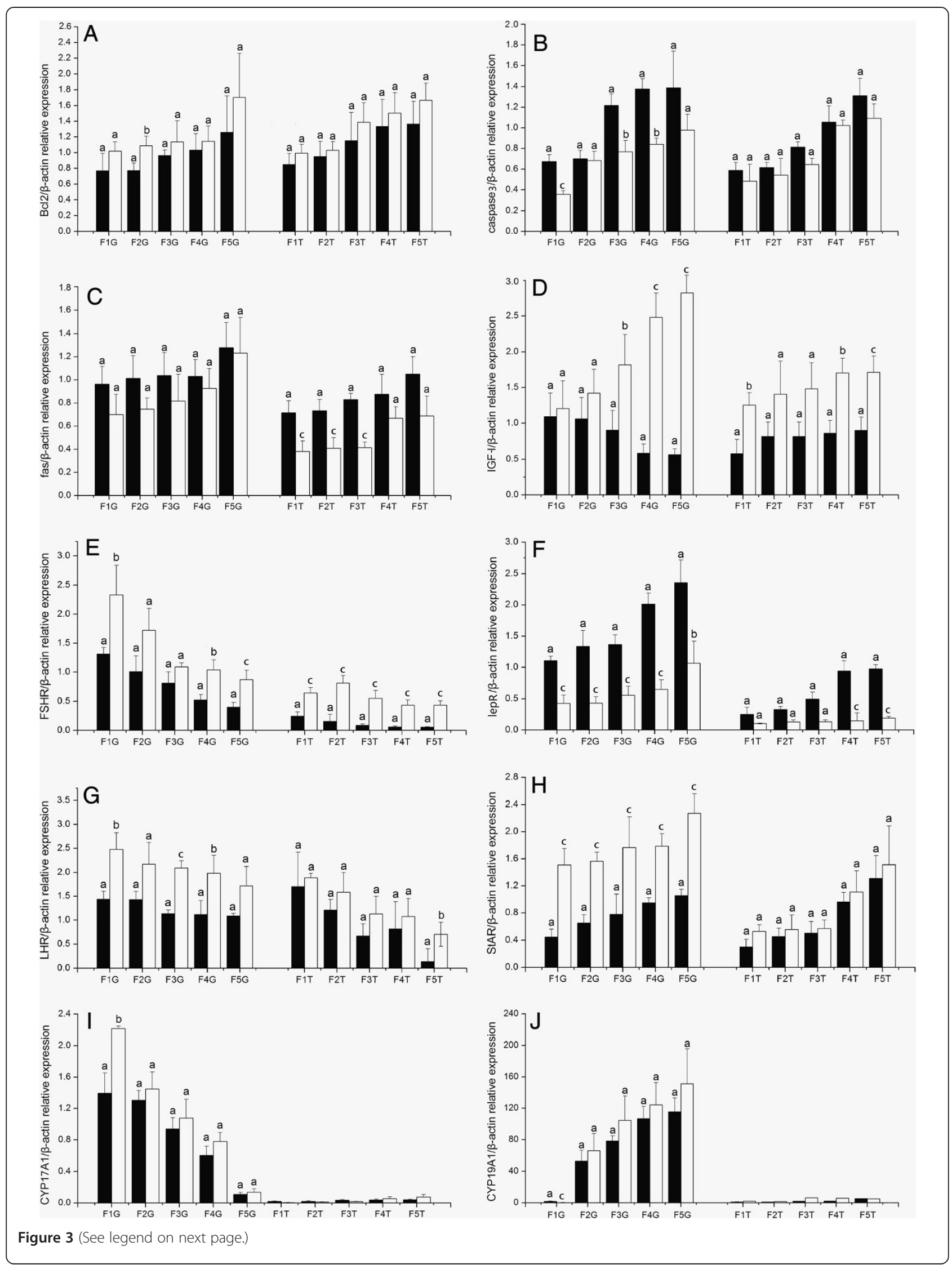


(See figure on previous page.)

Figure 3 The levels of mRNA expression relative to $\beta$-actin of ten genes in thegranulosa (G) and thecal (T) layer of various size ovarian follicles in Control hens $(\square, \mathbf{n}=\mathbf{8})$ and cLEPR Immunized hens $(\mathbf{a}, \mathbf{n}=\mathbf{8})$. (A) bcl2 (B) caspase3 (C) fas (D) IGF-/ (E) FSHR (F) lepR (G) LHR (H) StAR (I) CYP17A1 (J) CYP19A1. Fn represents the hierarchical order of follicle size, with the largest follicle designated as F1. Vertical bars represent the standard errors of the mean. Means not marked by a common letter are significantly different (a-b: $P<0.05 ; a-c: P<0.01$ ).

$(P<0.05)$ following cLEPR immunization. The expression of the anorexic genes, lepR, POMC and MC4R, however, were significantly up-regulated (Figure 5).

\section{Discussion}

Through immunization approach, we have shown that generating anti-cLEPR ECD antibody caused ovarian follicle atresia by up-regulating the expression of apoptotic genes, and down-regulating the expression of prodevelopment genes, thus caused decreases in egg laying in chicken hens. These results indicate that manipulating leptin receptor activities using antibody allows the study of the regulatory roles of leptin in avian ovarian follicular development and egg laying.

In this study, the immunization approach was adopted for producing leptin receptor binding molecules. The anticLEPR antibodies generated appeared to enhance leptin signal transduction, as was demonstrated by the higher proportion of phosphorylated STAT3 protein, a key protein in leptin receptor signal transduction [27-29], in the liver tissues of cLEPR Immunized hens. This result accords to our unpublished observation of enhanced leptin receptor signaling in cLEPR Immunized rats. In addition, the expression level of PPAR $\gamma$ mRNA was down-regulated in adipose tissue in cLEPR-immunized hens. This effect agrees with the previous reports that administration of leptin down-regulated $P P A R Y$ mRNA expression in the adipose tissue $[39,40]$. The up-regulation of $P P A R \gamma$ mRNA expression in the liver of cLEPR-immunized hens also jibed with the up-regulation of PPARY mRNA in cultured porcine adipose explants [40], which suggested a complex regulation of PPARY by leptin. Nevertheless, these results demonstrated that anti- CLEPR antibody mimicked the bioaction of leptin to enhance LEPR signal transduction. In the present study, the antigen we prepared composed of the $200\left(101^{\text {st }}\right.$ to $\left.300^{\text {th }}\right)$ amino acid residues residing in the $\mathrm{N}$-terminus CK-F3 domain of LEPR [41]. In two other studies with rats and chicken pullets, immunization against the sequence from $582^{\text {nd }}$ to $796^{\text {th }}$ amino acid residues of LEPR, in the F3-F3-F3 domain proximal to the cellular membrane, also enhanced LEPR signaling, reduced adipose tissue deposition [unpublished data], reduced live weight, while increased feed intake [unpublished data]. Results of our study and the above results indicate that antibodies bound to LEPR could trigger a signal transduction that stimulated metabolism. It appears that antibodies directed against many epitopes of LEPR ECD could trigger a receptor signal transduction. This may be due to the nature of LEPR, which exists as a dimer [42,43], hence the binding of any molecule, including antibody, to the dimer would lead to the formation of a molecule trimer that will cause receptor signal transduction $[41,43]$.

Leptin receptor that mediates leptin bioactivity is widely expressed by various tissues [44-46]. Our results showed that lepR is expressed in both granulosa and theca layers, with the expression level being higher in granulosa than in theca tissue. These results were consistent with the results previous reported by Cassy et al. [47]. In both studies, the lepR expression level decreases as the follicle enlarges, which might suggest a weaker expression of lepR in large more mature follicles diminished the negative regulatory role of leptin [47]. This form of regulation could be compared to the direct inhibition by leptin of gonadotropin and growth factor stimulated steroid hormone production by cultured rat granulosa cells [15-17]. Moreover, the expression of ovarian lepR was up-regulated by ad libitum feeding of the breeder hens [47], which increased plasma leptin
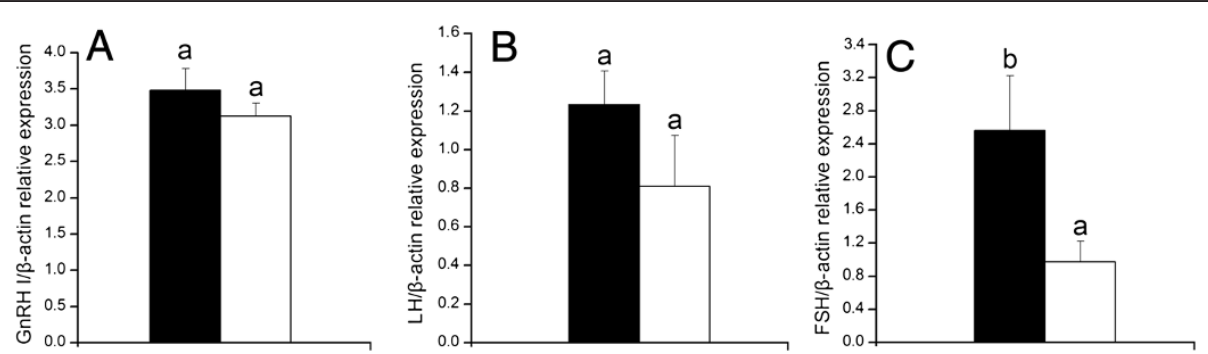

Figure 4 The levels of mRNA expression relative to $\beta$-actin in hypothalamus and pituitary gland in Control hens $(\square, \mathrm{n}=8)$ and $\mathrm{cLEPR}$ Immunized hens $(\mathbf{\square}, \mathbf{n}=\mathbf{8})$. (A) GnRH-I mRNA expression in hypothalamus (B) $L H \beta$ mRNA expression in pituitary gland (C) FSH $\beta$ mRNA expression in pituitary gland. Vertical bars represent the standard errors of the mean. Means not marked by a common letter are significantly different (a-b: $P<0.05)$. 

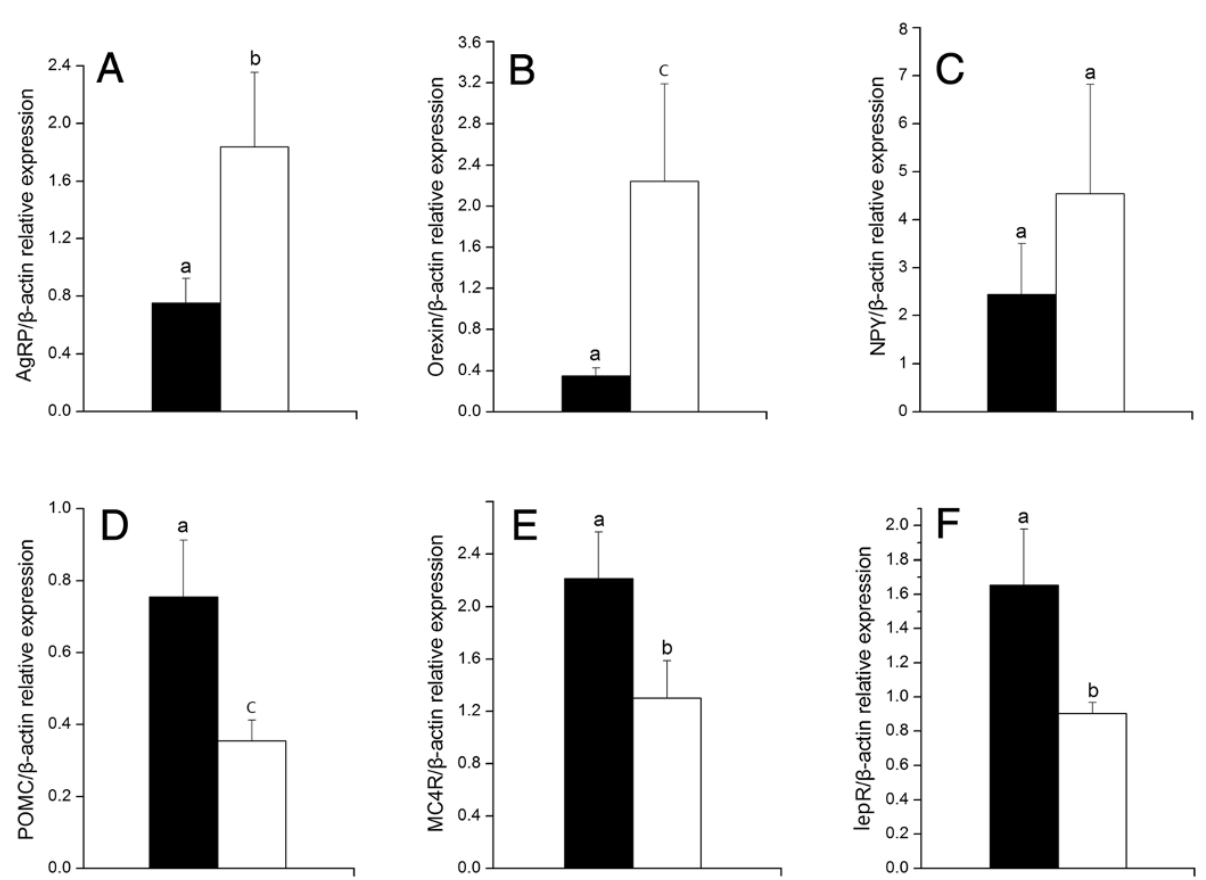

Figure 5 mRNA expression levels relative to $\beta$-actin of six genes in hypothalamus in Control hens $(\square, \mathrm{n}=\mathbf{8})$ and $\mathrm{cLEPR}$ Immunized hens $(\mathbf{\square}, \mathbf{n}=\mathbf{8})$. A) AgRP mRNA expression (B) orexin mRNA expression (C) NPY mRNA expression (D) POMC mRNA expression (E) MC4R mRNA expression (F) lepR mRNA expression. Vertical bars represent the standard errors of the mean. Means not marked by a common letter are significantly different (a-b: $P<0.05 ; a-c: P<0.01)$.

concentrations [23]. Likewise, our study showed upregulation by immunization against cLEPR ECD. In many circumstances, cytokine hormones such as GH and leptin could up-regulate gene expression of its own receptors $[48,49]$, thus results from our study and those from previous studies suggest that an up-regulation of lepR expression in ovarian tissues by ad libitum feeding and overweight hens was caused also by a molecule directed to lepR, which could be leptin or a molecule analogous to it, a possibility which is beyond the scope of the present study.

Both the ad libitum feeding [47] and immunization caused an up-regulation of lepR which was more pronounced in smaller F4 or F5 follicles. Thus the lepR mediated negative regulation of ovarian follicular development could be stronger in these small LYFs, or in even smaller follicles such as SYF and LWF. As expected, upon being slaughtered on Day 5 after the $4^{\text {th }}$ CLEPR immunization, severe atresia of SYFs occurred, causing a significant decrease to the number of healthy SYFs compared to the Control hens. Though the number of LYFs and the daily egg laying rate was only slightly decreased shortly for 5 days, after the $4^{\text {th }}$ CLEPR immunization, atresia of LYFs was also observed following longer lag by about Day 10 after administration of LEPR (unpublished observations). Therefore the negative regulation by anti-cLEPR antibody first appeared in SYFs, and then gradually extended to
LYFs as the antibody titers continued to rise following each administration of antigen, even though the more mature larger LYFs were more resistant to leptin attenuation. This effect by anti-cLEPR antibody was also reflected by the stronger down-regulations of IGF-I and FSHR, but upregulation of lepR in smaller than in larger LYFs. The ultimate effect is the decrease in egg laying rate in CLEPR Immunized hens. There also existed a dose dependent effect of anti-cLEPR antibody titer on reduction of laying rate between the primary and first booster immunizations. However laying rate also recovered to the level in the control hens after the initial drop when the antibody titers were still high, as was seen prior to the $2^{\text {rd }}$ and $3^{\text {th }}$ booster immunizations. Further, the higher titer after the $2^{\text {nd }}$ booster immunization was associated with a less degree of drop in egg laying rate, compared with the situation after the $1^{\text {st }}$ booster immunization. It is currently unknown whether the developing follicles could become refractory to persistent antibody stimulation, and still developed to ovulation. The other explanation is that more antibodies could be generated towards the 'foreign' leading peptide derived from the expression vector, instead of to the 'self' CLEPR domain in the recombinant antigen used. Antibodies to the leading peptide would not bind to CLEPR and not interfere ovarian follicle development. In this study, the number of LWFs was not affected by cLEPR immunization, which may suggest the development and 
function of LWFs may be free from leptin regulation. This assumption was supported by the finding that gonadotrophin receptor was not expressed in these class of follicles $[50,51]$, and that the leptin effect was mediated together with gonadotrophin and growth factor regulators [15-17]. The interruption of egg laying following cLEPR immunization is comparable to the reduced or even erratic egg laying in ad libitum fed, overweight fast growing breeder hens $[20,21]$. In the latter, there was an overgrowth of ovarian follicles, resulting in more than one SYFs recruited together into the hierarchical development during each ovulation/oviposition cycle [52,53], which results in presence of an extraordinary number of LYFs, a phenomenon akin to the polycystic ovary syndrome in obese humans [54]. However, despite of the overgrowth, the LYFs in overweight hens were never as large as those in restrictedly fed low weight hens, nor as high as steroid hormone production per follicle [20]. These could indicate that the largest follicles were not as mature as those of restrictedly fed low weight hens, and were not able to secrete sufficient steroid hormones to trigger pre-ovulatory LH surge or could not respond to it, thus leading to a reduced egg laying rate [21]. In addition, despite the overgrowth, follicle atresia was often observed especially at SYFs and small LYFs [53]. This phenomenon again indicated that some metabolic or endocrine factors associated with high nutrition intake and overweight might induce cell apoptosis and atresia of the small follicles, similar to the atresia caused by anti-LEPR antibody.

The anti-LEPR antibody is not able to cross the blood-brain barrier, therefore cLEPR immunization does not affect hypothalamic GnRH $I$ and $L H$ gene expressions in pituitary gland. On the contrary, a lack of negative feedback hormone regulation by oestrogen and inhibin due to the atresia of SYFs and especially LYFs was observed. The gene expression of FSH became significantly up-regulated in the pituitary gland. These results indicated that the anti-cLEPR antibody did not impair hypothalamic-pituitary functionality over reproductive function, and perturbation of the egg laying should reside at ovarian follicles. The atresia of SYFs and most probably LYFs was associated with up-regulation of apoptotic genes caspase 3 and fas, and down- regulation of anti-apoptotic genes $b c l 2$ and IGF-I. Except from the case of fas, the effect of immunization against cLEPR was more severe, especially for IGF-I, on smaller LYFs, F4 and F5, and possibly even SYFs, whose expressions were not analyzed. These results also indicate the atretic effects of anti-cLEPR antibodies have exerted first to SYFs and smaller LYFs. Previously, Sirotkin and Grossmann had shown that low and moderate levels of leptin inhibited expressions of apoptotic genes and stimulated expression of anti-apoptotic gene $b c l 2$ in cultured chicken ovarian follicle tissue [22]. However the reverse was true when leptin concentration in the culture medium was further increased [22]. It seemed that the anti-cLEPR antibody generated following immunization in this study had mimicked an effect created by high levels of leptin concentration. This further explains why only low numbers of SYFs and LYFs undergo atresia in ad libitum fed overweight hens, whose leptin levels could be very low and any effect could be mild compared with the high antibody titer in this study. Besides, low level of leptin stimulated, while high level decreased the release of progesterone and estradiol by cultured ovarian follicular tissue [22]. This phenomenon was parallelled by the decrease in the expressions of $L H R$, FSHR, StAR and CYP17A1 in our study. These results further indicated that gonadotropin hormone receptor response and steroid hormone secretion competence were reduced by the anti-cLEPR antibody affected cells and follicles.

The rapid growth of LYFs during hierarchical growth occurs with the deposition of large amount of yolk lipids and the associated proteins vitellogenin and very low density lipoprotein [55]. When follicular growth is interrupted, so are the synthesis and secretion of progesterone. In the mammals, a high circulating concentration of progesterone during the late pregnancy functions to induce a state of leptin resistance, so to further enhance food intake even when a positive energy balance is already reached [56-58]. In our study, such effect was expressed as a decrease in feed intake, when laying drop and follicular atresia occurred after cLEPR immunization, or when the ovarian follicles stopped secreting progesterone. The plasma concentrations of HDL in cLEPR Immunized chickens were significantly lower than those in the Control chickens. The plasma concentration of LDL in Immunized CLEPR chickens was significantly higher than in the Control chickens. These results accord with the results previous reported by Maki [59]. In addition, blood concentrations of glucose and triglycerides in the normal laying Controls hens were significantly higher than those in the Immunized hens. These results also suggest a state of 'leptin resistance' in the normal laying Control hens. Both a reduction of hypothalamic expression of $O b-R b$ and an increase in plasma leptin binding protein were implicated to fulfill the leptin resistance effect of progesterone [58]. The results of this study favored the latter theory: because the lepR expression in hypothalamus was increased, yet expressions of the orexigenic genes, Orexin, NPY and $A g R P$ were down regulated, and those of anorexigenic genes, $M C 4 R$ and $P O M C$ up-regulated. These results were in direct contrast to the up-regulation of orexigenic genes, but down regulation of anorexigenic genes in LEPR immunized growing rats [unpubilished data] and also chicken pullets [unpublished data]. In these growing animals free from progesterone interference, the anti-cLEPR 
antibody stimulated metabolism, decreased fat deposition and even body weight, as well as leptin secretion, thus stimulated appetite and feed intake. Results from our study demonstrate the importance of progesterone in regulation of feed intake in the laying hens.

\section{Conclusions}

Immunizing against LEPR ECD in hens generated antibodies that mimic leptin bioactivity by enhancing LEPR signal transduction. This regulated apoptotic gene expression in ovarian follicles, down-regulated the expression of genes supporting follicular development and hormone secretion, leading to follicle atresia and interruption of egg laying. Inhibition of progesterone secretion due to failure of follicle development also lowered feed intake. The results of this study demonstrate immunization against LEPR ECD may be utilized as a tool for studying biofunctions of chicken LEPR.

\section{Abbreviations}

AgRP: Agouti-related peptide gene; BSA: Bovine serum albumin; CYP17A1: Cytochrome P450, family 17, subfamily A, polypeptide 1; CYP19A1: Cytochrome P450, family 19, subfamily A, polypeptide 1; ECD: Extra-cellular domain; ELISA: Enzyme linked immunosorbent assay; FSH: Follicle stimulating hormone; FSHR: Follicle stimulating hormone receptor; HDL: High-density lipoprotein; IGF-I: Insulin-like growth factor 1; LDL: Low-density lipoprotein; LEPR: Leptin receptor; LH: Luteinizing hormone; LHR: Luteinizing hormone receptor; LWF: Large white follicle; LYF: Large yellow follicles; MC4R: Melanocortin 4 receptor; NPY: Neuropeptide Y; POMC: Proopiomelanocortin; PPARy: Peroxisome proliferator-activated receptor gammar; StAR: Steroidogenic acute regulated protein; SYF: Small yellow follicle; VLDL: Very low-density lipoprotein.

\section{Competing interests}

The authors declare that they have no competing interests.

\section{Authors' contributions}

MML and ZDS designed the study, while XWL and CLW constructed the LEPR ECD protein. MML and SQW carried out the animal experiment, collected and analyzed the samples. MML and ZDS prepared the manuscript with correction input by ZC. All authors read and approved the final manuscript.

\section{Acknowledgements}

This study was supported by Postdoctoral Foundation of Jiangsu Province

(026096511202), and National Science Foundation of China (grant no. 31372314).

\section{Author details}

${ }^{1}$ Laboratory of Animal Breeding and Reproduction, Institute of Animal Science, Jiangsu Academy of Agricultural Sciences, Nanjing 210014, China. ${ }^{2}$ College of Animal Sciences, South China Agricultural University, Guangzhou 510642, China.

Received: 12 January 2014 Accepted: 12 March 2014

Published: 20 March 2014

\section{References}

1. Pelleymounter MA, Cullen MJ, Baker MB, Hecht R, Winters D, Boone T, Collins F: Effects of the obese gene product on body weight regulation in ob/ob mice. Science 1995, 269:540-543.

2. Houseknecht KL, Baile CA, Matteri RL, Spurlock ME: The biology of leptin: a review. J Anim Sci 1998, 76:1404-1420.

3. Taouis M, Chen JW, Daviaud C, Dupont J, Derouet M, Simon J: Cloning the chicken leptin gene. Gene 1998, 208:239-242.
4. Chehab FF, Lim ME, Lu R: Correction of the sterility defect in homozygous obese female mice by treatment with the human recombinant leptin. Nat Genet 1996, 12:318-320.

5. Blache D, Tellam RL, Chagas LM, Blackberry MA, Vercoe PE, Martin GB: Level of nutrition affects leptin concentrations in plasma and cerebrospinal fluid in sheep. J Endocrinol 2000, 165:625-637.

6. Ahima RS, Prabakaran D, Mantzoros C, Qu D, Lowell B, Maratos-Flier E, Flier JS: Role of leptin in the neuroendocrine response to fasting. Nature 1996, 382:250-252.

7. Dridi S, Raver N, Gussakovsky EE, Derouet M, Picard M, Gertler A, Taouis M: Biological activities of recombinant chicken leptin C4S analog compared with unmodified leptins. Am J Physiol Endocrinol Metab 2000, 279:E116-E123.

8. Campfield LA, Smith FJ, Guisez Y, Devos R, Burn P: Recombinant mouse OB protein: evidence for a peripheral signal linking adiposity and central neural networks. Science 1995, 269:546-549.

9. Friedman JM, Halaas JL: Leptin and the regulation of body weight in mammals. Nature 1998, 395:763-770.

10. Licinio J, Caglayan S, Ozata M, Yildiz BO, de Miranda PB, O'Kirwan F, Whitby R, Liang L, Cohen P, Bhasin S, Krauss RM, Veldhuis JD, Wagner AJ, DePaoli AM, McCann SM, Wong ML: Phenotypic effects of leptin replacement on morbid obesity, diabetes mellitus, hypogonadism, and behavior in leptin-deficient adults. Proc Natl Acad Sci U S A 2004, 101:4531-4536.

11. Chehab FF, Mounzih K, Lu R, Lim ME: Early onset of reproductive function in normal female mice treated with leptin. Science 1997, 275:88-90.

12. Cummingham MJ, Clifton DK, Steiner RA: Leptin's actions on the reproduction axis: perspectives and mechanisms. Biol Reprod 1999, 60:216-222

13. Foster DL, Nagatani S: Physiological perspectives on leptin as a regulator of reproduction: role in timing puberty. Biol Reprod 1999, 60:205-215.

14. Paczoska-Eliasiewicz HE, Gertler A, Proszkowiec M, Proudman J, Hrabia A Sechman A, Mika M, Jacek T, Cassy S, Raver N, Rzasa J: Attenuation by leptin of the effects of fasting on ovarian function in hens (Gallus domesticus). Reproduction 2003, 126:739-751.

15. Agarwal SK, Vogel K, Weitsman SR, Magoffin DA: Leptin antagonizes the insulin-like growth factor-I augmentation of steroidogenesis in granulosa and theca cells of the human ovary. J Clin Endocrinol Metab 1999, 84:1072-1076.

16. Zachow RJ, Magoffin DA: Direct intraovarian effects of leptin: impairment of the synergistic action of insulin-like growth factor-I on folliclestimulating hormone dependent estradiol-17 beta production by rat ovarian granulosa cells. Endocrinology 1997, 138:847-850.

17. Zachow RJ, Weitsman SR, Magoffin DA: Leptin impairs the synergistic stimulation by transforming growth factor-beta of follicle-stimulating hormone-dependent aromatase activity and messenger ribonucleic acid expression in rat ovarian granulosa cells. Biol Reprod 1999, 61:1104-1109.

18. Kikuchi N, Andoh K, Abe Y, Yamada K, Mizunuma H, Ibuki Y: Inhibitory action of leptin on early follicular growth differs in immature and adult female mice. Biol Reprod 2001, 65:66-71.

19. Duggal PS, Van Der Hoek KH, Milner CR, Ryan NK, Armstrong DT, Magoffin DA, Norman RJ: The in vivo and in vitro effects of exogenous leptin on ovulation in the rat. Endocrinology 2000, 141:1971-1976.

20. Buchanan S, Robertson GW, Hocking PM: Ovarian steroid hormone production in a multiple ovulating male line and a single ovulating traditional line of turkeys. Reproduction 2001, 121:277-285.

21. Onagbesan OM, Metayer S, Tona K, Williams J, Decuypere E, Bruggeman V: Effects of genotype and feed allowance on plasma luteinizing hormones, follicle-stimulating hormones, progesterone, estradiol levels, follicle differentiation, and egg production rates of broiler breeder hens. Poult Sci 2006, 85:1245-1258.

22. Sirotkin AV, Grossmann R: Leptin directly controls proliferation, apoptosis and secretory activity of cultured chicken ovarian cells. Comp Biochem Physiol A Mol Integr Physiol 2007, 148:422-429.

23. Chen SE, McMurtry JP, Walzem RL: Overfeeding-induced ovarian dysfunction in broiler breeder hens is associated with lipotoxicity. Poult Sci 2006, 85:70-81.

24. Friedman-Einat M, Boswell T, Horev G, Girishvarma G, Dunn IC, Talbot RT, Sharp PJ: The chicken leptin gene: has it been cloned? Gen Comp Endocrinol 1999, 15:354-363.

25. Sharp PJ, Dunn IC, Waddington D, Boswell T: Chicken leptin. Gen Comp Endocrinol 2008, 58:2-4. 
26. Pitel $F$, Faraut $T$, Bruneau $G$, Monget $P$ : Is there a leptin gene in the chicken genome? Lessons from phylogenetics, bioinformatics and genomics. Gen Comp Endocrinol 2010, 167:1-5.

27. Horev G, Einat P, Aharoni T, Eshdat Y, Friedman-Einat M: Molecular cloning and properties of the chicken leptin-receptor (CLEPR) gene. Mol Cell Endocrinol 2000, 162:95-106.

28. Ohkubo T, Tanaka M, Nakashima K: Structure and tissue distribution of chicken leptin receptor (cOb-R) mRNA. Biochim Biophys Acta 2000, 1491:303-308.

29. Adachi $H$, Takemoto $Y$, Bungo $T$, Ohkubo $T$ : Chicken leptin receptor is functional in activating JAK-STATpathway in vitro. J Endocrinol 2008, 97:335-342.

30. Lõhmus $M$, Sundström LF, Silverin B: Chronic administration of leptin in Asian Blue Quail. J Exp Zool A Comp Exp Biol 2006, 305:13-22.

31. Paczoska-Eliasiewicz HE, Proszkowiec-Weglarz M, Proudman J, Jacek T, Mika M, Sechman A, Rzasa J, Gertler A: Exogenous leptin advances puberty in domestic hen. Domest Anim Endocrinol 2006, 31:211-226.

32. Shi ZD, Shao XB, Chen N, Yu YC, Bi YZ, Liang SD, Williams JB, Taouis M: Effects of immunisation against leptin on feed intake, weight gain, fat deposition and laying performance in chickens. Br Poult Sci 2006, 47:88-94.

33. Bowers CY, Momany FA, Chang D, Hong A, Chang K: Structure-activity relationships of a synthetic pentapeptide that specifically releases $\mathrm{GH}$ in vitro. Endocrinology 1980, 106:663-667.

34. Chen C, Wu D, Clarke IJ: Signal transduction systems employed by synthetic GH-releasing peptides in somatotrophs. J Endocrinol 1996, 148:381-386.

35. Lopez-Liuchi JV: Hormone delivery: small synthetic molecular mimics. Eur J Endocrinol 1998, 139:481-483.

36. Frohman LA, Kineman RD, Kamegai J, Park S, Teixeira LT, Coschigano KT, Kopchic JJ: Secretagogues and the somatotrope: signaling and proliferation. Recent Prog Horm Res 2000, 55:269-291.

37. Jeyakumar M, Moudgal NR: Immunization of male rabbits with sheep luteal receptor to LH results in production of antibodies exhibiting hormone-agonistic and -antagonistic activities. J Endocrinol 1996, 150:431-443.

38. Li WL, Liu Y, Yu YC, Huang YM, Liang SD, Shi ZD: Prolactin plays a stimulatory role in ovarian follicular development and egg laying in chicken hens. Domest Anim Endocrinol 2011, 41:57-66.

39. Zhou Y, Wang Z, Higa M, Newgard CB, Unger RH: Reversing adipocyte differentiation: implications for treatment of obesity. Proc Natl Acad Sci USA 1999, 96:2391-2395.

40. Ajuwon KM, Kuske JL, Anderson DB, Hancock DL, Houseknecht KL, Adeola $\mathrm{O}$, Spurlock ME: Chronic leptin administration increases serum NEFA in the pig and differentially regulates PPAR expression in adipose tissue. J Nutr Biochem 2003, 14:576-583.

41. Fong TM, Huang RR, Tota MR, Mao C, Smith T, Varnerin J, Karpitskiy W Krause JE, Van der Ploeg LH: Localization of leptin binding domain in the leptin receptor. Mol Pharmacol 1998, 53:234-240.

42. Devos R, Guisez Y, Van der Heyden J, White DW, Kalai M, Fountoulakis M, Plaetinck G: Ligand-independent dimerization of the extracellular domain of the leptin receptor and determination of the stoichiometry of leptin binding. J Biol Chem 1997, 272:18304-18310.

43. Couturier $C$, Jockers R: Activation of the leptin receptor by a ligandinduced conformational change of constitutive receptor dimers. J Biol Chem 2003, 278:26604-26611.

44. Kumar L, Panda RP, Hyder I, Yadav VP, Sastry KV, Sharma GT, Mahapatra RK, Bag S, Bhure SK, Das GK, Mitra A, Sarkar M: Expression of leptin and its receptor in corpus luteum during estrous cycle in buffalo (Bubalus bubalis). Anim Reprod Sci 2012, 135:8-17.

45. Richards MP, Poch SM: Molecular cloning and expression of the turkey leptin receptor gene. Comp Biochem Physiol B Biochem Mol Biol 2003 136:833-847.

46. Ni Y, LV J, Wang S, Zhao R: Sexual maturation in hens is not associated with increases in serum leptin and the expression of leptin receptor mRNA in hypothalamus. J Anim Sci Biotechnol 2013, 4:24

47. Cassy S, Metayer S, Crochet S, Rideau N, Collin A, Tesseraud S: Leptin receptor in the chicken ovary: potential involvement in ovarian dysfunction of ad libitum-fed broiler breeder hens. Reprod Biol Endocrinol 2004, 2:72.

48. Ono M, Miki N, Murata Y, Demura H: Hypothalamic growth hormonereleasing factor (GRF) regulates its own receptor gene expression in vivo in the rat pituitary. Endocr J 1998, 45(Suppl):S85-S88.
49. Mitchell SE, Nogueiras R, Morris A, Tovar S, Grant C, Cruickshank M, Rayner DV, Dieguez C, Williams LM: Leptin receptor gene expression and number in the brain are regulated by leptin level and nutritional status. J Physiol 2009, 587:3573-3585.

50. Johnson AL, Bridgham JT, Wagner B: Characterization of a chicken luteinizing hormone receptor (cLH-R) complementary deoxyribonucleic acid, and expression of CLH-R messenger ribonucleic acid in the ovary. Biol Reprod 1996, 55:304-309.

51. Lovell TM, Gladwell RT, Groome NP, Knight PG: Differential effects of activin $A$ on basal and gonadotrophin-induced secretion of inhibin $A$ and progesterone by granulosa cells from preovulatory (F1-F3) chicken follicles. Reproduction 2002, 124:649-657.

52. Sharp PJ, Dunn IC, Cerolini S: Neuroendocrine control of reduced persistence of egg-laying in domestic hens: evidence for the development of photorefractoriness. J Reprod Fertil 1992, 94:221-235.

53. Hocking PM: Biology of Breeding Poultry. In Feed Restriction. Volume 17. 1st edition. Edited by Hocking PM. Bodmin: the MPG Books Group; 2009:307-330.

54. Rajendran S, Willoughby SR, Chan WP, Liberts EA, Heresztyn T, Saha M, Marber MS, Norman RJ, Horowitz JD: Polycystic ovary syndrome is associated with severe platelet and endothelial dysfunction in both obese and lean subjects. Atherosclerosis 2009, 204:509-514.

55. Johnson AL: Reproduction in the female. In Sturkie's Avian Physiology. 5th edition. Edited by Whittow GC. New York: Springer; 2000:569-596.

56. Mounzih K, Qiu J, Ewart-Toland A, Chehab FF: Leptin is not necessary for gestation and parturition but regulates maternal nutrition via a leptin resistance state. Endocrinology 1998, 139:5259-5262.

57. Grueso E, Rocha M, Puerta M: Plasma and cerebrospinal fluid leptin levels are maintained despite enhanced food intake in progesterone-treated rats. Eur J Endocrinol 2001, 144:659-665

58. Seeber RM, Smith JT, Waddell BJ: Plasma leptin-binding activity and hypothalamic leptin receptor expression during pregnancy and lactation in the rat. Biol Reprod 2002, 66:1762-1767.

59. Maki KC, Beiseigel JM, Jonnalagadda SS, Gugger CK, Reeves MS, Farmer MV, Kaden VN, Rains TM: Whole-grain ready-to-eat oat cereal, as part of a dietary program for weight loss, reduces low-density lipoprotein cholesterol in adults with overweight and obesity more than a dietary program including low-fiber control foods. J Am Diet Assoc 2010, 110:205-214.

doi:10.1186/1477-7827-12-25

Cite this article as: Lei et al.: Leptin receptor signaling inhibits ovarian follicle development and egg laying in chicken hens. Reproductive Biology and Endocrinology 2014 12:25.

\section{Submit your next manuscript to BioMed Central and take full advantage of:}

- Convenient online submission

- Thorough peer review

- No space constraints or color figure charges

- Immediate publication on acceptance

- Inclusion in PubMed, CAS, Scopus and Google Scholar

- Research which is freely available for redistribution

Submit your manuscript at www.biomedcentral.com/submit
C Biomed Central 